\title{
Defoliation and Fruit Removal Effects on Papaya Fruit Production, Sugar Accumulation, and Sucrose Metabolism
}

\author{
Lili Zhou, ${ }^{1}$ David A. Christopher, ${ }^{2}$ and Robert E. Paull ${ }^{3}$ \\ Department of Tropical Plant and Soil Sciences, College of Tropical Agriculture and Human Resources, \\ University of Hawaii at Manoa, 3190 Maile Way, Honolulu, HI 96822-2279
}

\begin{abstract}
AdDITIONAL INDEX wORDS. sucrose phosphate synthase, sucrose synthase, acid invertase, continual defoliation, fruit thinning, Carica papaya

Abstract. Papaya (Carica papaya L.) source size and sink strength were modified by a single defoliation or continual defoliation and fruit thinning. Fruit set, development, weight, total sugar (sum of sucrose, fructose, and glucose), sucrose phosphate synthase (SPS), sucrose synthase (SS), and acid invertase (AI) enzyme activities in response to defoliation and fruit thinning were determined. The effects of defoliation and fruit thinning varied with weather conditions, plant growth conditions, and cultivar. Removal of $75 \%$ of the leaves significantly reduced new flower production and fruit set, and decreased ripe fruit total soluble solids (TSS), while $50 \%$ defoliation did not reduce new fruit set or ripe fruit TSS. When every third leaf from the oldest leaf was not removed, the number of new flowers was reduced by $47 \%$ more than when the same number of leaves was removed from the oldest to younger leaves. Continual removal of old leaves reduced new fruit set, fruit weight, and TSS in the 168 day experimental period. Fruit thinning increased new fruit set and ripe fruit TSS. Larger fruit size, faster fruit development, lower respiration rate, and higher sugar contents and AI activity were observed in immature (young) fruit when old fruit were removed. AI activity was reduced during early fruit development and increased again in mature fruit in plants subjected to defoliation, and suggested a role for AI in mature fruit sugar accumulation, while SS activity declined significantly in fruit $\mathbf{1 5 4}$ and $\mathbf{1 7 5}$ days after anthesis and in mature fruit when plants were subjected to continual defoliation. SPS activity was not affected significantly by defoliation or fruit thinning. Source-sink balance was critical for papaya fruit set, development, and sugar accumulation and each mature leaf was able to provide photoassimilate for about three fruit.
\end{abstract}

Plants with a large leaf area often have increased photosynthetic capacity and at a given fruit load can have higher fruit total soluble solids (TSS) levels (Hubbard et al., 1990; Welles and Buitelaar, 1988). An optimum leaf number and area for development of individual fruit has been reported for kiwi fruit (Actinidia deliciosa C.S. Laing and A.R. Fergusson) (Antognozzi et al., 1992; Snelgar and Martin, 1997), mango (Mangifera indica L.) (Chacko et al., 1982), grapefruit (Citrus X paradisi MacFad.) (Fishler et al., 1983), apple [Malus sylvestris (L.) Mill. var. domestica (Borkh.) Mansf.] (Palmer et al., 1991) and sweet cherry (Prunus avium L.) (Roper and Loescher, 1987). The leaf to fruit ratio (source-sink ratio) also affects the final fruit size and composition of apples (Hansen, 1982) and plums [Prunus $\mathrm{x}$ domestica L.] (Toldam-Anderson and Hansen, 1993). Limiting carbohydrate export from leaves, naturally or artificially induced, reduces fruit size and quality in tomato (Lycopersicon esculenteum Mill.) (Bertin, 1995), muskmelon [Cucumis melo L. (Reticulatus group)] (Hubbard et al., 1990), grape (Vitis vinifera L.) (Koblet et al., 1994), peach [Prunus persica (L.) Batsch (Peach group)] and pome fruits (Pavel and Dejong, 1993). Sexual expression is also altered by carbohydrate limitation in many

Received for publication 3 Aug. 1999. Accepted for publication 2 June 2000. College of Tropical Agriculture and Human Resources journal series 4467. This research was funded by USDA-CSREES Grants 96-34135-2842 and 98-341356458. The research represents a portion of a dissertation submitted by the L. Zhou for the PhD in Horticulture. We thank Gail Uruu and Nancy Chen for technical assistance. The cost of publishing this paper was defrayed in part by the payment of page charges. Under postal regulations, this paper therefore must be hereby marked advertisement solely to indicate this fact.

${ }^{1}$ Postdoctoral fellow.

${ }^{2}$ Associate professor, Department of Molecular Biosciences and Biosystems Engineering.

${ }^{3}$ Professor; to whom reprint requests should be addressed. e-mail: paull@hawaii.edu. hermaphroditic species (Awada, 1967; Spears and May, 1988; Wilson, 1983).

Papaya (Carica papaya) is a herbaceous, dicotyledonous plant with a single main stem, terminating with a crown of large palmately lobbed leaves (Nakasone, 1986). Most cultivars have flowers borne in a modified cymose inflorescence that appear in every leaf axis just below the growing point (Nakasone, 1986). Plants flower and fruit continuously after flower initiation commences and the leaves generally senesce and abscise before the fruit reaches maturity. The availability of carbohydrate exported from leaves to fruit determines papaya fruit production and sweetness. However, foliage injury can occur in papaya because of insects [e.g., broad mite (Hemitarsonemus latus Banks)], diseases such as powdery mildew (Oidium caricae F. Noack), and papaya ring spot virus (Marler et al., 1993; Nakasone, 1986), and strong winds. This can lead to fruit with reduced sweetness that fail to meet the commercial grade standard of 11.5\% TSS (Paull et al., 1997).

The relationship between papaya leaf area, fruit production, and sweetness is only partially understood. Defoliation increases papaya staminate flower number and decreases trunk growth and leaf dry weight (DW), whereas deflowering decreases staminate flower number and increases trunk growth and leaf DW (Awada, 1967). Papaya leaf pruning to 15 functional leaves does not affect fruit production or TSS of the fruit (Ito, 1976), while thinning papaya to one fruit per node increases fruit size and has no effect on fruit sugar (Martinez, 1988). However, the number of mature leaves or their total area to fruit number or weight was not reported in the aforementioned papers. The critical leaf to fruit ratio or whether there are cultivar differences that impact fruit production and sweetness are unknown. The time from loss of papaya source leaves before fruit set and mature fruit size and sweetness are affected has not been determined. As new leaves are formed following defoliation, the 
time required for fruit set, size, and sweetness to recover are similarly unknown. The objectives of this research were to determine papaya fruit set, fruit growth, ripe fruit sweetness, and the impact on sugar metabolism in response to defoliation and fruit thinning. This research attempts to answer the question as to what is the relationship between leaf number and area and fruit number, weight, and sugar content of a species that is continually producing new leaves and flowers and has fruit at every stage of development on a single main stem.

\section{Materials and Methods}

Plant material. 'Sunset' and 'UH801' papaya plants were grown at the Poamoho Experimental Station in central Oahu, Hawaii. 'Line-8' and 'Kapoho' plants were grown on the nearby fields of Dole Food Company. Plants of 'Kamiya' were grown at a private farm, on the north shore of Oahu. Plants were grown using commercial production practices of spacing $(2 \times 3.5 \mathrm{~m})$, fertilization, irrigation, and insect and disease control (Yee et al., 1974). At the spacing used, canopy overlap was $<10 \%$, and hence individual uniform plants were selected, generally five individual trees per treatment, each tree being a separate replicate, unless otherwise noted. Also, all treatments were imposed when the papaya plants first began to produce ripe fruit, unless otherwise stated.

Single DEFOLIATION (EXPT. 1). This experiment was conducted on 'Sunset' papaya, during Hawaii's warm season (1998 May to September) and consisted of five treatments: 1) nontreated (control $), 2)$ defoliation $(50 \%)=$ oldest mature green leaf to youngest, 3 ) defoliation $(75 \%)$ oldest to youngest, 4 ) defoliation $(75 \%)$ in a spiral (three of every four leaves, from the oldest leaf to the youngest removed), and 5) fruit thinned (40\% removed from oldest to the youngest). The leaves and fruit in the different treatments were removed at the beginning of the experiment and fruit at the color break to $30 \%$ skin yellow stage (mature fruit) were harvested weekly. Fresh weight (FW) and TSS were determined after the fruit ripened for $7 \mathrm{~d}$ at $22^{\circ} \mathrm{C}$. TSS was determined by refractometry. New flower and fruit set were recorded at weekly intervals for 6 weeks starting from the first week of the experiment. If no fruit occurred in a leaf axil, the node was recorded as flower or fruit aborted.

Defoliation AND SUgars (EXPT. 2). Defoliated ' Kamiya' trees (75\% defoliation, from the oldest to youngest leaves) were compared to control trees in Spring 1995. Fruit was harvested at the color break to $30 \%$ yellow skin stage (harvest maturity). Fruit FW was determined on the day of harvest. Fruit mesocarp TSS, sugar and sugar enzyme activities [SPS (sucrose phosphate synthetase), SS (sucrose synthetase), and acid invertase (AI)] were determined on the day of harvest and on different fruit $6 \mathrm{~d}$ after storage at $22{ }^{\circ} \mathrm{C}$. Fruit flesh and seed FW, and DW of individual fruit were determined weekly for 6 weeks. DW percentage, at each stage, was determined on three $10 \mathrm{~g}$ tissue or seed samples dried at $60^{\circ} \mathrm{C}$ for 6 d.

Defoliation AND FRUit DEVElopMent (EXPT. 3). Flowers of 'Kapoho' and 'Line-8' papaya were tagged at anthesis from June to Nov. 1996. Defoliation was conducted in Dec. 1996 when the first tagged fruit reached color break. The four treatments were: 1) nontreated (control); 2) defoliation (66\%) two of every three leaves removed in a spiral from the oldest leaf) 3) fruit thinning (two of every three fruit removed from the oldest fruit), and 4) fruit thinning plus defoliation. Mature fruit were harvested weekly and TSS and FW were determined $7 \mathrm{~d}$ after harvest. Younger fruit below the mature leaves, at different ages, were harvested for up to 3 weeks after defoliation. Fruit flesh and seed FW, DW, flesh TSS, sugar level, and SPS, SS, and AI enzyme activity were determined on the mesocarp tissue.

Continual Defoliation. Sixteen 'Sunset' papaya trees were assigned randomly to the treatments when the first fruit on the plants reached maturity: 1) control (no leaves or immature fruit removed during the experimental period), 2) continual defoliation (DL) $=12$ to 14 of the green leaves $(60 \%$ defoliation from the oldest to the youngest leaves) were removed 6 Dec. 1995, leaving about nine leaves (petiole longer than the axil of the younger leaf) on the plant, (two or three additional leaves were removed weekly, maintaining the same number of leaves during the experimental period), 3) fruit removal(DF) treatment $(80 \%$ of fruit from the bottom upwards were removed at the beginning of the experiment and no additional fruit removed until fruit were ready to ripen), and 4) fruit removal plus continual defoliation (DF + DL). Flowers were tagged weekly at anthesis. New flower and fruit set were recorded for the first 8 weeks from the start of the treatment. Total new fruit set was recorded from the first tagged fruit to the youngest fruit at the end of experiment. Mature fruit were harvested weekly and fruit weight and TSS were determined. Fruit at four stages of development (140, 154, and 175 $\mathrm{d}$ after anthesis (DAA) and mature fruit) from four different treatments were harvested 29 May 1996. Fruit FW, respiration, skin, flesh and seed color, seed DW, flesh sugars (sucrose, glucose, and fructose), SPS, SS, and AI enzyme activities were determined. Skin and flesh color were determined with a Minolta colorimeter (Chromameter CR-300; Minolta Co., Ramsey, N.J.) and expressed as the Commission Internationale de l'Eclairage (CIE) 'L', 'a', 'b' for each fruit. Individual fruit were sealed for $1 \mathrm{~h}$ in a $970-\mathrm{mL}$ jar and 1-mL headspace gas samples were removed for $\mathrm{CO}_{2}$ determination with an infrared $\mathrm{CO}_{2}$ gas analyzer (LI-6251; LICOR, Inc., Lincoln, $\mathrm{Nebr}$.) and fruit respiration rate expressed as $\mathrm{mL} \cdot \mathrm{h}^{-1} \cdot \mathrm{kg}^{-1} \mathrm{FW}(\mathrm{Clegg}$ et al., 1978).

ENZYMe AND SUgar ASSAYs. Fruit from the single defoliation experiment on control and defoliated 'Sunset' plants were harvested at the color break to $30 \%$ yellow stages and stored for $7 \mathrm{~d}$ at $22{ }^{\circ} \mathrm{C}$ before enzyme activity assay. In the fruit thinning treatment, fruit at the same ages were either harvested at the $30 \%$ yellow stage then ripened at $22{ }^{\circ} \mathrm{C}$ or picked $7 \mathrm{~d}$ later after ripening on the plant. Fruit from the continual defoliation experiment at four development stages (140, 154, and 175 DAA and mature fruit) was sampled on the day of harvest, frozen in liquid nitrogen and stored at $-80^{\circ} \mathrm{C}$ until analyzed. SPS, SS, and AI were extracted following procedures of Hubbard et al., (1989) with slight modifications. Frozen mesocarp tissue was ground in liquid nitrogen in a chilled mortar and pestle. Three grams of powder was transferred to a centrifuge tube that contained $12 \mathrm{~mL}$ of extraction buffer (100 mM 3-[Nmorpholino]propanesulfonic acid (MOPS-NaOH) ( $\mathrm{pH} 7.5), 5$ $\mathrm{mm} \mathrm{MgCl}_{2}, 1 \mathrm{~mm}$ ethylenediaminetetraacetic acid (EDTA), 2.5 $\mathrm{mm}$ dl-dithiothreitol (DTT), bovine serum albumin (BSA) at 0.5 $\mathrm{mg} \cdot \mathrm{mL}^{-1}, 2 \%(\mathrm{v} / \mathrm{v})$ glycerol, $1 \mathrm{~mm}$ phenylmethylsulfonyl fluoride (PMSF), and $0.05 \%(\mathrm{v} / \mathrm{v})$ Triton X-100) and homogenized for 30 s to $1 \mathrm{~min}$ at high speed in an UltraTurrax homogenizer (Tekmar Co. Cincinnati, Ohio). After centrifugation at $10,000 \mathrm{~g}_{n}$ for $10 \mathrm{~min}, 5 \mathrm{~mL}$ of supernatant was desalted and concentrated through Centriflo membrane cones (CF-25; Amicon Inc., Beverly, Mass.) by three additions of desalting buffer (50 mm MOPS-NaOH (pH 7.5) $5 \mathrm{~mm}$ $\mathrm{MgCl}_{2}, 2.5 \mathrm{~mm}$ DTT, BSA at $0.5 \mathrm{mg} \cdot \mathrm{mL}^{-1}$, and $1 \mathrm{~mm}$ PMSF). The volume of final solution was measured and the concentration factor of extracts calculated.

The reaction mixture $(70 \mu \mathrm{L})$ used to determine SPS activity contained 50 mм MOPS-NaOH (pH 8.0), $15 \mathrm{~mm} \mathrm{MgCl}_{2}, 10 \mathrm{~mm}$ fructose 6-phosphate, $30 \mathrm{~mm}$ glucose 6-phosphate, $20 \mathrm{~mm}$ UDPG, 
Table 1. Effect of a single defoliation ( $50 \%$ or $75 \%$ defoliation) and fruit thinning ( $40 \%$ of fruit removed in a spiral from the oldest, at the beginning of experiment) on new 'Sunset' papaya fruit set and the number of nodes that had no flowers or fruit and were regarded as aborted during the 6-week experimental period. The defoliation treatments were applied by two methods: leaves were removed from the oldest to the youngest leaf, and every fourth leaf was retained (spiral) from the oldest leaf.

\begin{tabular}{lrc}
\hline & \multicolumn{2}{c}{ No./plant $^{2}$} \\
\cline { 2 - 3 } Treatment & Fruit set & Aborted nodes \\
\hline Control & $18.4 \mathrm{~b}$ & $0.4 \mathrm{c}$ \\
Defoliation & & \\
$\quad 50 \%$ (bottom upward) & $19.2 \mathrm{~b}$ & $0.4 \mathrm{c}$ \\
$\quad 75 \%$ (bottom upward) & $13.6 \mathrm{c}$ & $3.6 \mathrm{~b}$ \\
$\quad 75 \%$ (spiral) & $7.4 \mathrm{~d}$ & $8.8 \mathrm{a}$ \\
Fruit thinned (40\%) at beginning & $22.5 \mathrm{a}$ & $0 \mathrm{c}$
\end{tabular}

$\overline{{ }^{\mathrm{z}} \text { Mean separation }(\mathrm{n}=5) \text { within columns by Waller-Duncan } \mathrm{k} \text { ratio } t \text { test, }}$ $P<0.01$.

and 45 L desalted enzyme extract. Reaction mixtures were incubated at $37{ }^{\circ} \mathrm{C}$ with shaking and the reaction terminated at 0 and 30 min by addition of $70 \mu \mathrm{L} 30 \% \mathrm{KOH}$ and placing the tubes in a boiling water bath for $10 \mathrm{~min}$. After cooling, $1 \mathrm{~mL}$ of $0.14 \%(\mathrm{w} / \mathrm{v})$ anthrone in $14 \mathrm{M} \mathrm{(v/v)} \mathrm{H}_{2} \mathrm{SO}_{4}$ was added (Hubbard et al., 1989) and incubated at $40^{\circ} \mathrm{C}$ for $20 \mathrm{~min}$. After cooling, color development was measured at $620 \mathrm{~nm}$. The assay for SS in the sucrose direction was identical to that of SPS except that the reaction mixtures contained $40 \mathrm{~mm}$ fructose and no fructose 6-phosphate and glucose 6-phosphate (Hubbard et al., 1989). Invertase was assayed in $60 \mu \mathrm{L}$ of 0.1 $\mathrm{M} \mathrm{K}_{2} \mathrm{HPO}_{4} 0.1 \mathrm{M}$ citrate buffer ( $\mathrm{pH} 5.0$ ), $20 \mu \mathrm{L} 0.1 \mathrm{M}$ sucrose, and 20 $\mu \mathrm{L}$ of concentrated or diluted enzyme extract at $22^{\circ} \mathrm{C}$. The reaction was stopped by adding $1 \mathrm{~mL}$ borate buffer (pH 9.0). Reducing sugar was determined by adding $0.2 \mathrm{~mL} 1 \%$ (wt/vol) cyanoacetamide, boiling the mixture for $10 \mathrm{~min}$, and reading absorbency at $276 \mathrm{~nm}$ with glucose and fructose as standards (Gross, 1988).

TSS was determined by refractive index and was the average of two measurements made on the flesh at the equator of each fruit. Sucrose, fructose, and glucose were separated and quantified by high-performance liquid chromatography (HPLC) from retention times and peak areas using known standards (Paull et al., 1984). The sum of the three sugars was regarded as total sugar. DW percentage, at each stage, was determined on three 10-g tissue samples or seeds dried at $60^{\circ} \mathrm{C}$ for $6 \mathrm{~d}$. Fruit flesh and seed DW accumulation were calculated from DW percentage multiplied by the average fruit $\mathrm{FW}$ in the same sample.

DAta Analysis. Statistical analysis was performed using general linear model or correlation model procedures of the Statistical Analysis System (SAS Institute, Inc., Cary, N.C.). The WallerDuncan k ratio $t$ test was used for mean separation in the tables and LSD in the figures. Correlation coefficients between fruit sugar and SS and AI enzyme activity at four developmental stages and four treatments were obtained by using the enzyme and sugar data of the same aged fruit or at one stage earlier for the enzymatic activity with the next stage's sugar level.

\section{Results}

NEW Flower AND FRUIT SET. Papaya flower and fruit set were reduced by a single defoliation and increased by fruit thinning (Table 1). Flower abortion increased nine fold and new fruit set was reduced $30 \%$ in 'Sunset' plants subjected to $75 \%$ defoliation from the oldest to youngest leaves (Table 1). Plants in which the leaves were removed in a spiral manner had significantly lower fruit set (47\%) and higher fruitlet abortion (2.4 fold) than plants defoliated from the oldest leaves upwards (Table 1). Fruit thinning increased fruit set by increasing the number of fruit per node (Table 1). There was no significant difference between $0 \%$ and $50 \%$ defoliation in the number of nodes without fruit and new fruit set.

Fruit removal and continual defoliation significantly altered new flower production and fruit set (Table 2). After 6 weeks, plants subjected to fruit removal had the highest flower set, followed by fruit removal plus defoliation and control plants while the plants in the continual defoliated treatment had the lowest flower set (Table 2). At 8 weeks, there was no significant difference in new fruit set between the fruit removed and fruit removal plus defoliation treatment. Defoliated plants produced one-third less fruit than the controls, and one-quarter of that of plants in the fruit removal treatment. At the end of the experiment, fruit removal plants had twice the fruit set of the control plants. Plants that had been defoliated continually had only one-fourth the fruit set of the control plants (Table 2). No significant difference in total fruit set was found between the fruit removal plus continual defoliation and control plants during the entire experimental period. The leaf to fruit ratio (fruit number per leaf) changed from the beginning of experiment to the end of experiment ( 24 weeks later), from 2.4 to 2.0 in control plants, 6.8 to 1.4 in continual defoliated plants, 0.5 to 2.9 in fruit removed plants, and 1.9 to 4.4 in the fruit removed plus continual defoliated plants (Table 2).

RIPE FRUIT TSS AND FRUIT WEIGHT. Removal of $70 \%$ to $75 \%$ of the leaves during Hawaii's warm season significantly decreased TSS levels in ripe fruit within 14 to $21 \mathrm{~d}$ after defoliation of 'Sunset' and 'Kamiya' papaya (Figs. 1 and 2A). Fruit TSS recovered about 42 d after defoliation. Defoliation also reduced flesh DW percentage

Table 2. Effect of continual leaf defoliation ( $60 \%$ reduction) and fruit removal ( $80 \%$ of fruit removed from bottom upward) of 'Sunset' papaya at the beginning of experiment, and fruit removal plus continual defoliation on new flower, and fruit set for 6 and 8 weeks after treatment and ripe fruit number, total soluble solids (TSS), and weight, 24 weeks after defoliation (6 Dec. 1995 to 22 May 1996). Fruit per leaf ratio are presented as initial (at the beginning of the experiment) and final (by the end of experiment) for each treatment.

\begin{tabular}{|c|c|c|c|c|c|c|c|c|}
\hline \multirow[b]{3}{*}{ Treatment } & \multicolumn{3}{|c|}{ No. per plant ${ }^{2}$} & & & & & \\
\hline & \multirow{2}{*}{$\frac{\text { Flowers }}{6 \text { weeks }}$} & \multicolumn{2}{|c|}{ Fruit set } & \multicolumn{3}{|c|}{ Ripe fruit $^{y}$} & \multicolumn{2}{|c|}{ Fruit to leaf ratio } \\
\hline & & 8 weeks & 24 weeks & No. & TSS & Wt $(\mathrm{g})$ & Initial & Final \\
\hline Control & $11 \mathrm{~b}^{\mathrm{z}}$ & $15 \mathrm{~b}$ & $28 \mathrm{~b}$ & $54 \mathrm{a}$ & $12.2 \mathrm{a}$ & $303 \mathrm{a}$ & $2.4 \mathrm{~b}$ & $2.0 \mathrm{c}$ \\
\hline Defoliated & $4 \mathrm{c}$ & $4 \mathrm{c}$ & $7 \mathrm{c}$ & $47 \mathrm{a}$ & $10.4 \mathrm{~b}$ & $234 \mathrm{~b}$ & $6.8 \mathrm{a}$ & $1.4 \mathrm{~d}$ \\
\hline Fruit removed & $20 \mathrm{a}$ & $23 \mathrm{a}$ & $61 \mathrm{a}$ & $5 \mathrm{~b}$ & & $0.5 \mathrm{c}$ & $2.9 \mathrm{~b}$ & \\
\hline Fruit removed + defoliated & $16 \mathrm{~b}$ & $21 \mathrm{a}$ & $29 \mathrm{~b}$ & $4 \mathrm{~b}$ & & $1.9 \mathrm{~b}$ & $4.4 \mathrm{a}$ & \\
\hline
\end{tabular}

${ }^{\mathrm{z}}$ Mean separation $(\mathrm{n}=4)$ within columns by Walter-Duncan k ratio $t$ test, $P<0.05$.

${ }^{\mathrm{y}}$ Means for ripe fruit TSS and weight were obtained from the mean of all ripe fruit per plant. 
(Fig. 2B) and fruit weight (Table 2). However, defoliation effects were not consistent between 'Kapoho' and 'Line-8' (Table 3) during the cooler rainy season (Dec., 1996). Defoliation significantly lowered fruit TSS in 'Kapoho', but not in 'Line-8', during the 6 week period after treatment. Defoliation reduced ripe fruit weight in 'Line-8', but not 'Sunset' (data not presented), or 'Kapoho' (Table 3). Fruit thinning increased ripe fruit weight in 'Kapoho' and reduced fruit weight in 'Line-8' (Table 3) and had no significant effect on 'Sunset' and 'Kamiya' (data not presented). Defoliation plus fruit thinning on 'Kapoho' had no significant effect on fruit weight and TSS values compared to the controls (Table 3).

The number of mature fruit per plant was not significantly different between the defoliated and control treatment until 5 months of defoliation (Fig. 3A). Continual defoliation significantly reduced ripe fruit TSS (15\%) and fruit weight (23\%) during the 168 d experimental period when compared to the controls (Table 2), due mainly to lower TSS and fruit weight between March and May (Fig. $3 \mathrm{~B}$ and $\mathrm{C}$ ). Fruit removal plus defoliation led to similar fruit weight but lower TSS levels than the controls (Table 4). Continual plant defoliation plus fruit removal (DF $+\mathrm{DL})$ maintained a higher leaf to fruit ratio during the initial experiment period (Table 2). As new fruit were set and developed and defoliation continued, final fruit TSS was reduced as the leaf to fruit ratio (Table 2) declined (Table 4).

FruIT DEVELOPMENT. When fruit were removed, the higher flesh 'a' color value, visible skin yellowing, and higher fruit TSS levels on the plant (Table 5) suggested earlier fruit maturation than fruit on the control plants. Continual defoliation reduced fruit weight but did not delay maturation in 'Sunset' as indicated by flesh and seed color when compared to control fruit 175 DAA (Table 5). However,

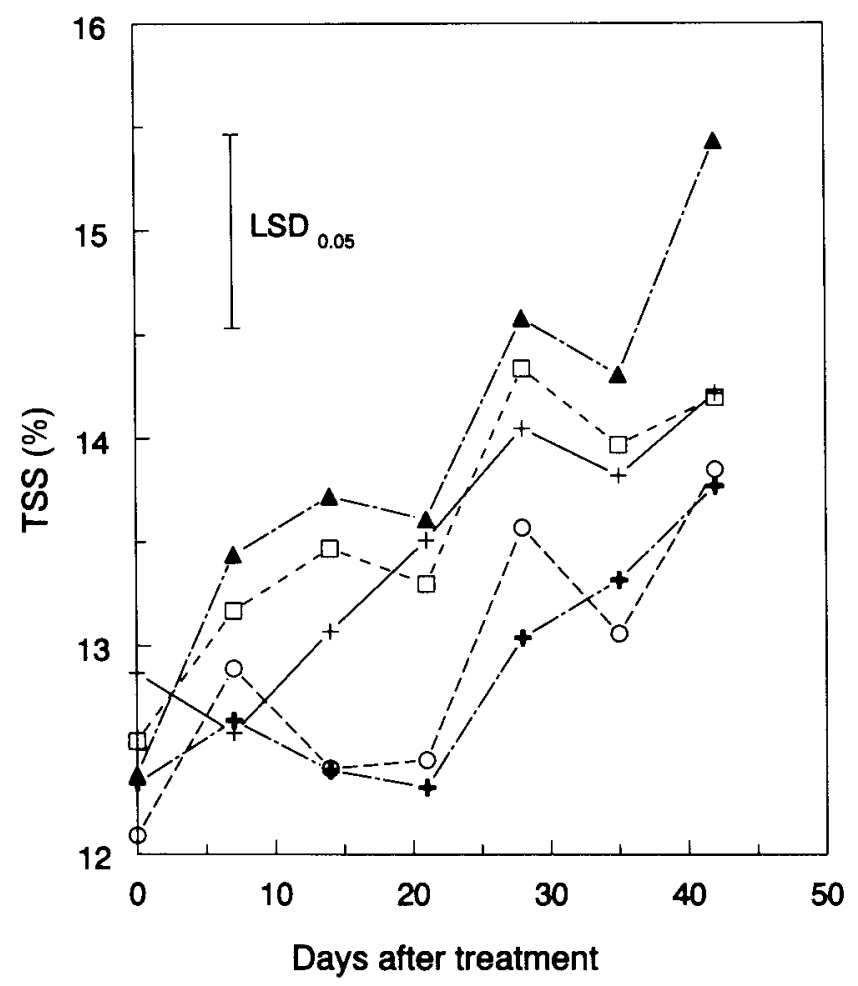

Fig. 1. Total soluble solids (TSS) in 'Sunset' papaya fruit subject to single defoliation and fruit thinning treatments: control $(+)$; fruit thinned $(\mathbf{\Delta}), \approx 40$ fruit removed; $50 \%$ of leaf number removed $(\square) ; 75 \%(\$)$ defoliation in a spiral where only every fourth leaf was retained from oldest to the youngest leaf; $75 \%$ bottom upward $(O)=75 \%$ defoliation from the oldest to youngest leaves. Fruit were harvested at color break stage and allowed to ripen at $22{ }^{\circ} \mathrm{C}$ before evaluation. young 'Kapoho' fruit growth was delayed by a single defoliation as indicated by lowered seed DW percentage $21 \mathrm{~d}$ after defoliation (Fig. 4) compared to the controls. Fruit thinning of 'Line-8' also increased young fruit sugar levels compared to the controls (Table $6)$.

There was no significant difference in fruit mesocarp $(\approx 91 \%)$ and seed percentage, seed weight ratio, and seed DW in ripe fruit (17\%), between fruit of a single defoliation and control treatments in 'Kamiya' (data not presented). However, defoliation significantly lowered mature fruit flesh DW percentage (Fig. 2B).

SPS, SS, AND AI ACTIVITY IN SINGLE DEFOLIATION. Fruit thinning doubled 'Sunset' full ripe fruit SS activity compared to the defoliated treatment (Table 7). Higher invertase activity was found generally in fruit from the defoliation treatment and the lowest activity was detected in fruit from the fruit thinned treatment but activity was not significantly different between treatments due to high sample variation (Table 7). There was a decrease in SPS and SS activities and an increase in AI enzyme activity after harvest. Defoliation, $28 \mathrm{~d}$ before harvesting, significantly increased mature fruit AI activity $1 \mathrm{~d}$ after harvest but not $6 \mathrm{~d}$ after harvest, in 'Kamiya' (data not presented). There was no significant difference in harvested fruit SPS, SS, and AI activities in 'Kapoho' and 'Line-8' between all treatments.

RESPIRATION, SUGAR, AND ENZYME ACTIVITIES IN CONTINUAL DEFOLIATION. Fruit at 140 and 154DAA had a higher respiration rate than at $175 \mathrm{DAA}$, the preclimacteric minimum stage of maturity (Fig. 5A). Fruit removal increased fruit sugar concentration 140, 154, and, 175 DAA compared to the controls (Fig. 5B). However, there was no significant difference in TSS at the color break stage of fruit
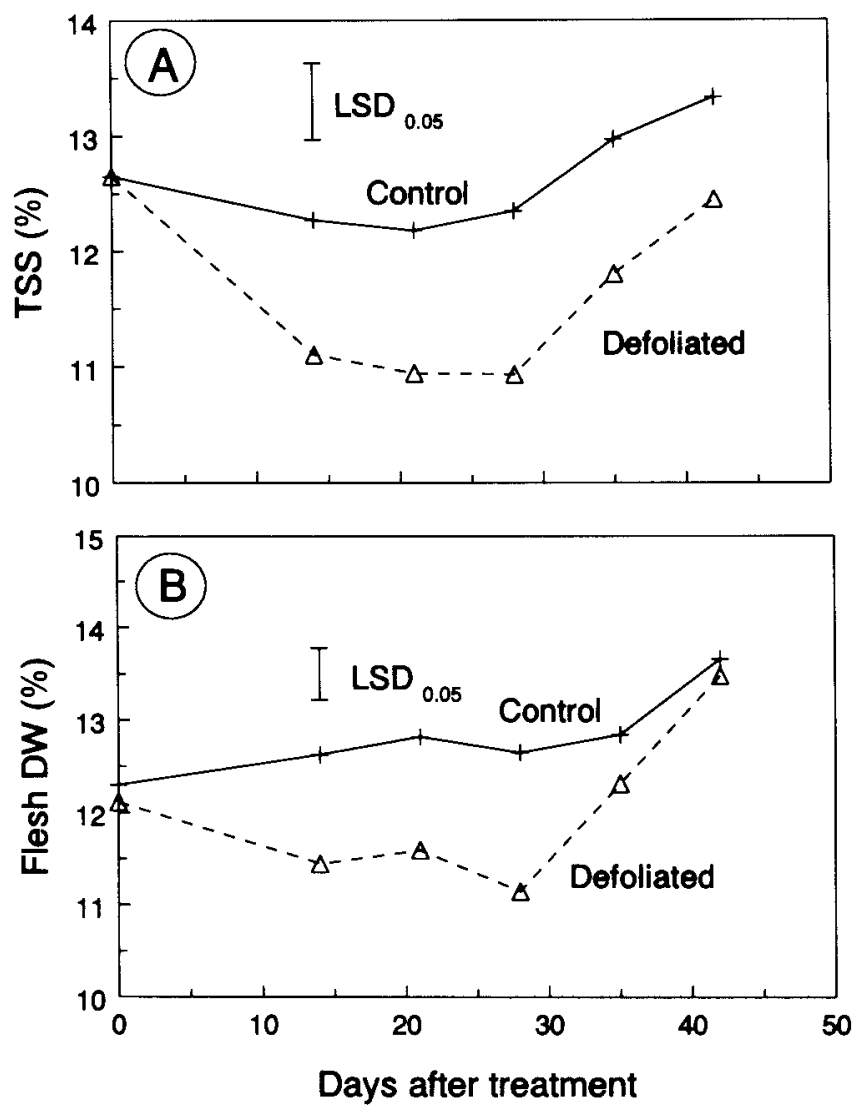

Fig. 2. (A) Fruit total soluble solids (TSS) and (B) fruit flesh dry weight percentage of 'Kamiya' papaya in response to a single defoliation $(65 \%)$, harvested at the color break stage and allowed to ripen at $22^{\circ} \mathrm{C}$, before evaluation. 
Table 3. Effect of defoliation and fruit thinning on fruit weight and total soluble solids (TSS) of ripe 'Kapoho' and 'Line-8' papaya. Data were pooled for fruit harvested $0,7,21,28$, and $42 \mathrm{~d}$ after treatment.

\begin{tabular}{|c|c|c|c|c|}
\hline \multirow[b]{2}{*}{ Treatment } & \multicolumn{2}{|c|}{ Fruit wt $(\mathrm{g})^{\mathrm{z}}$} & \multicolumn{2}{|c|}{ TSS $(\%)$} \\
\hline & Kapoho & Line-8 & Kapoho & Line- 8 \\
\hline Control & $353 b^{z}$ & $460 \mathrm{a}$ & $11.2 \mathrm{ab}$ & $11.4 \mathrm{~b}$ \\
\hline Defoliated & $344 \mathrm{~b}$ & $410 \mathrm{~b}$ & $10.9 \mathrm{c}$ & $11.0 \mathrm{~b}$ \\
\hline Fruit thinned & $380 \mathrm{a}$ & $404 \mathrm{~b}$ & $11.4 \mathrm{a}$ & $11.8 \mathrm{a}$ \\
\hline Defoliated + fruit thinned & $356 \mathrm{ab}$ & --- & $11.1 \mathrm{~b}$ & --- \\
\hline
\end{tabular}

${ }^{\mathrm{z}}$ Mean (n = 406 and 394 for fruit wt and TSS, respectively) separation within columns by Waller-Duncan $\mathrm{k}$ ratio $t$ test, $P<0.05$.

harvested from the fruit removal and the control plants (Table 4). Mature and 154 DAA fruit from the continual defoliation treatment had lower sugar concentrations, but no significant difference was detected between 140 and 175DAA fruit. Fruit sugar concentrations of plants receiving continual defoliation plus initial fruit removal were similar to those for continually defoliated plants alone except 175 DAA. SPS was low and increased from 140 DAA to 175 DAA but there was no significant difference among treatments (Fig. 5C), while SS activity was low and tended to increase during late fruit development (Fig. 5D) when sugars were accumulating (Fig. 5B).

Fruit at 154 and

175 DAA and

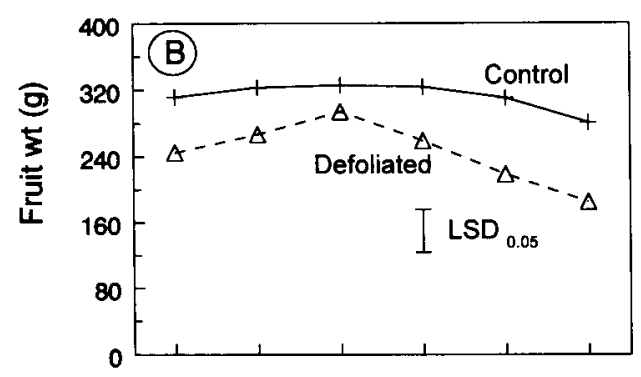
removal treat-
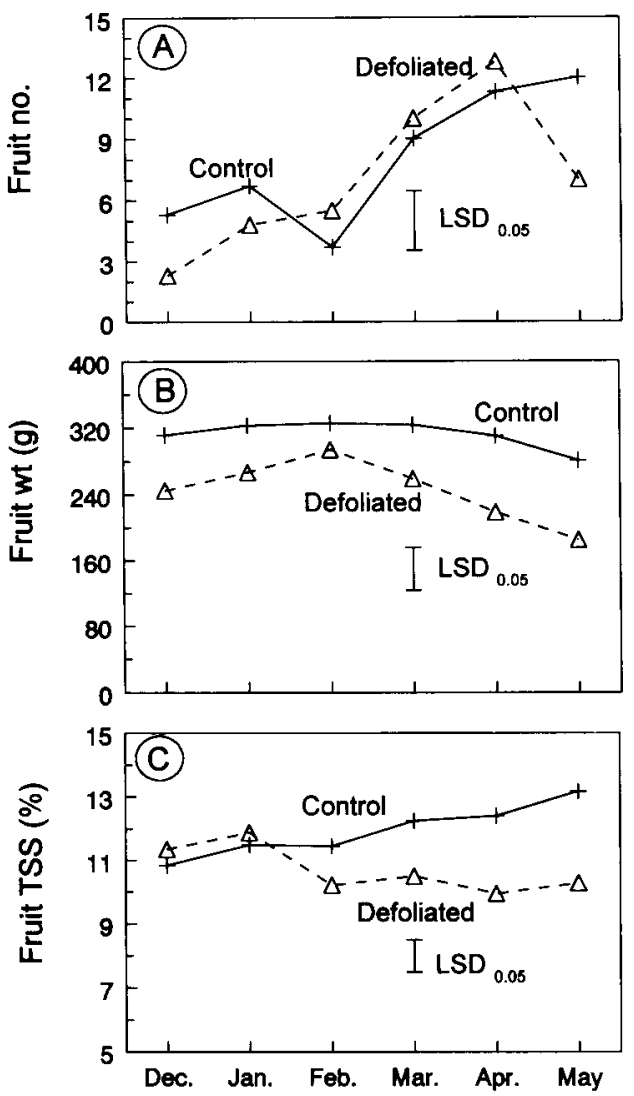

Harvest month

mature fruit

from the continual defoliation treatment and the fruit removal plus continually defoliated plants had lower SS activities than fruit from the control plants. No significant differences were found in SS activity at all four stages of fruit development between the fruit removal and the control treatments.

AI activity increased earlier in the 140 DAA fruit in the fruit ment than in the other treatments (Fig. 5E). No significant dif-

Fig. 3. (A) 'Sunset' papaya average mature fruit number per plant per month, (B) individual fruit weight, and $(\mathbf{C})$ fruit total soluble solids for a continual defoliation experiment conducted between Dec. 1995 and May 1996. The treatments were: nondefoliated (control) and continual weekly defoliation (60\% reduction) from Dec. 1995, to maintain nine leaves per plant. Fruit were harvested at the color break stage and allowed to ripen at $22^{\circ} \mathrm{C}$ before evaluation. Each symbol point represents the mean fruit harvested from the same four plants, four times each month. ferences in AI activity was detected in 154 and 175 DAA and mature fruit between fruit removal and control treatments. The rate of fruit AI activity from 154 to 175 DAA from the continual defoliated plants was lower than the controls then increased in the 175 DAA and mature fruit. There was a positive correlation between SS with sugar content among the treatments within the same aged fruit but no correlation was found in the four treatments [control, continual defoliated (60\%), $80 \%$ fruit removal, and continual defoliation plus $80 \%$ fruit removal] at the four development stages (Table 8). AI was only correlated with fruit glucose content $(r=0.51, P=0.05)$ in the four treatments at the four development stages (Table 8). Invertase activity at 140,154, and 175 DAA in the four treatments and at the three stages was highly correlated to sucrose, glucose, fructose and total sugar concentration at 154 and $175 \mathrm{DAA}$ and as the fruit began to ripen. For example, the correlation for AI versus glucose was $r=$ $0.80(P=0.01)$.

\section{Discussion}

Papaya is an indeterminate plant that develops simultaneously new leaves and fruit, and has fruit at all stages of development present on a single plant (Nakasone, 1986). Competition exists between vegetative and reproductive sinks and, between young and mature fruit sinks. Data herein indicated that for papaya, 50\% defoliation did not significantly affect fruit TSS or new fruit set rate (Fig. 1, Table 1). This result suggested that either or both photosynthate was not limiting or that the rate of leaf photosynthesis increased in defoliated papaya plants. Many other cultivated plants compensate for partial defoliation by increasing photosynthetic capacity of the remaining leaf area (Boucher et al., 1987; Layne and Flore, 1992, 1995; Von Caemmerer and Farquhar, 1984). Similarly, removal of $25 \%$ of the leaf area of tomato (Stacey, 1983) and cucumber (Cucumis sativus L.) plants (Ramirez et al., 1988) did not significantly reduce fruit yield or whole plant dry matter accumulation. Removing $50 \%$ of the leaf area of potted apple trees reduced DW accumulation by 40\% (Maggs, 1964). Initial results suggest an

Table 4. Ripe 'Sunset' papaya fruit number, weight, and total soluble solids (TSS) from plants subjected to complete defoliation, continual defoliation (60\% leaf removal), $80 \%$ fruit removal at the beginning of experiment, and fruit removed plus continual defoliation. Mature fruit were harvested between 8 to 29 May 1996, 5 months after treatment.

\begin{tabular}{lccc}
\hline \hline Treatment & $\begin{array}{c}\text { Fruit } \\
\text { per tree }\end{array}$ & $\begin{array}{c}\text { Fruit wt } \\
(\mathrm{g})\end{array}$ & $\begin{array}{c}\text { TSS } \\
(\%)\end{array}$ \\
\hline Control & $38 \mathrm{a}^{\mathrm{z}}$ & $270 \mathrm{~b}$ & $13.2 \mathrm{a}$ \\
Defoliated & $29 \mathrm{~b}$ & $173 \mathrm{c}$ & $10.4 \mathrm{c}$ \\
Fruit removed & $38 \mathrm{a}$ & $347 \mathrm{a}$ & $13.1 \mathrm{a}$ \\
Fruit removed + defoliated & $31 \mathrm{~b}$ & $261 \mathrm{~b}$ & $11.9 \mathrm{~b}$
\end{tabular}

${ }_{\mathrm{z}}$ Mean separation $(\mathrm{n}=4)$ within columns by Waller-Duncan $\mathrm{k}$ ratio $t$ test, $P<0.05$. 
Table 5. 'Sunset' papaya fruit maturity as judged by skin and flesh color, weight and total soluble solids from plants subjected to no defoliation (nontreated controls) and continual defoliation (60\% reduction), fruit removal ( $80 \%$ fruit removal at the beginning of experiment), and fruit removal plus continual defoliation, on fruit $175 \mathrm{~d}$ after anthesis. Seeds in fruit from all treatments were black and the fruit therefore judged to be mature. Fruit were harvest 29 May 1996.

\begin{tabular}{|c|c|c|c|c|c|}
\hline \multirow[b]{2}{*}{ Treatment } & \multicolumn{2}{|c|}{ Visible color } & \multirow{2}{*}{$\begin{array}{c}\text { Flesh }^{\mathrm{z}} \\
\text { CIE 'a' }\end{array}$} & \multirow{2}{*}{$\begin{array}{l}\mathrm{Wt} \\
(\mathrm{g})\end{array}$} & \multirow{2}{*}{$\begin{array}{l}\text { TSS } \\
(\%)\end{array}$} \\
\hline & Skin & Flesh & & & \\
\hline$\overline{\text { Control }}$ & Green & $30 \%$ red & $-4.08 c^{y}$ & $281 \mathrm{~b}$ & $6.6 \mathrm{~b}$ \\
\hline Defoliated & Green & $30 \%$ red & $-2.09 \mathrm{c}$ & $128 \mathrm{c}$ & $5.9 \mathrm{~b}$ \\
\hline Fruit removed & Light green & $70 \%$ red & $5.6 \mathrm{a}$ & $369 \mathrm{a}$ & $10.0 \mathrm{a}$ \\
\hline Fruit removed + defoliated & Light green & $50 \%$ red & $2.18 \mathrm{~b}$ & $290 \mathrm{~b}$ & $9.7 \mathrm{a}$ \\
\hline
\end{tabular}

가esh CIE 'a' value from minus to plus indicated color from green to red.

${ }^{\mathrm{y}}$ Mean separation $(\mathrm{n}=4)$ within columns by Waller-Duncan $\mathrm{k}$ ratio $t$ test, $P<0.05$.

increase in photosynthetic rate on the recently mature papaya leaves, within 5 d of partial defoliated plants (Reyes and Paull, unpublished data). Greater defoliation ( $60 \%$ to $75 \%$ leaves removed) did reduce papaya fruit TSS and fruit flesh dry matter percentage, 14 to $21 \mathrm{~d}$ after treatment (Figs. 1 and 2), suggesting that the compensatory ability of the plants was exceeded. Results also suggested that plant starch resources were minimal, or unavailable, to compensate for short-term leaf loss, although we observed starch in the papaya stems and petioles by I-KI staining (Jensen, 1962).

The effect of defoliation and fruit thinning on plant growth and development depends on the time of the defoliation and the number of leaves, flowers, or fruit removed (Lyrene, 1992; Mulas, 1997; Pavel and DeJong, 1993). When papaya plants had

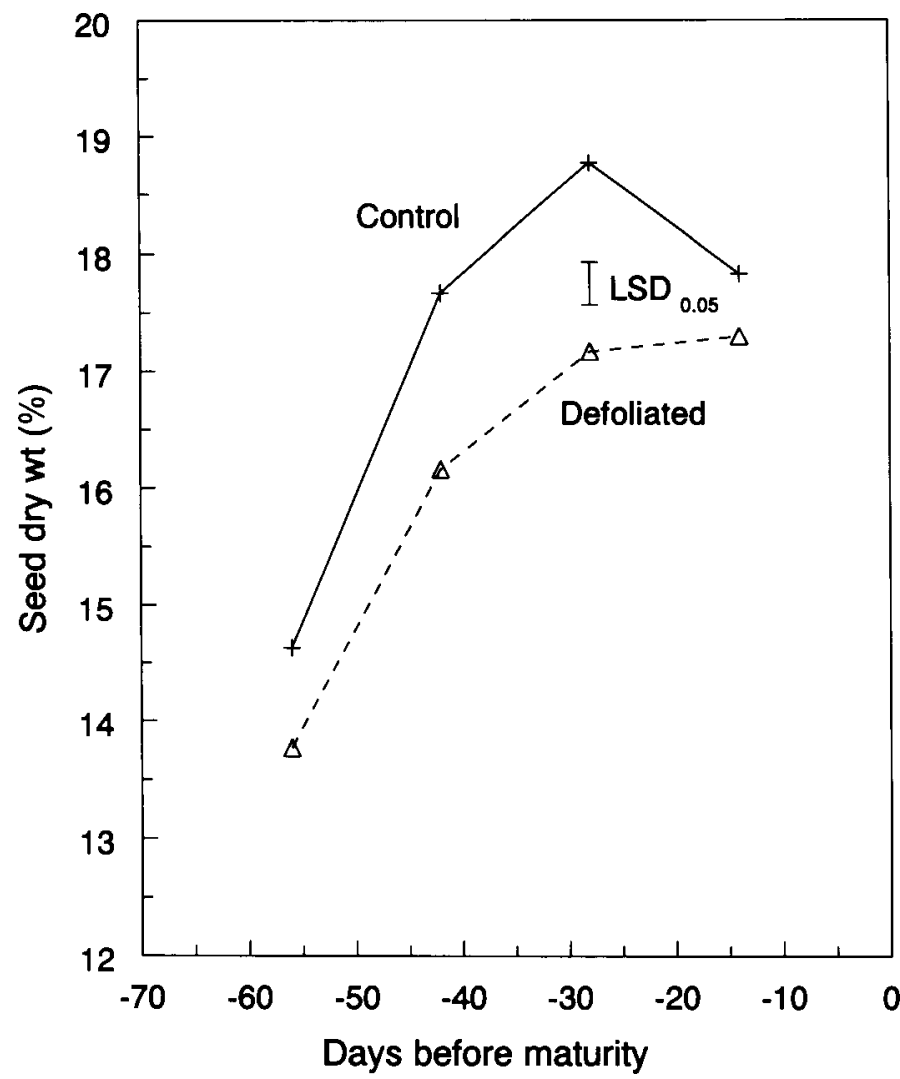

Fig. 4. Effect of defoliation on 'Kapoho' papaya young fruit seed dry weight (DW) percentage, 3 weeks after defoliation. The days before maturity were estimated from when the fruit on the control plant reach harvest maturity. The higher seed DW $(\%)$ of the control plants during the earlier stage of fruit development indicated higher seed maturity. a full fruit load (column), fruit TSS declined significantly 2 weeks after defoliation, then recovered in about 4 weeks (Figs. 1 and 2A), as new leaves developed and fewer new fruit were produced. When the plant fruit column did not have fruit at all stages of development, defoliation did not lower TSS in the following 2 months of fruit production (Fig. 3C). Continual defoliation appeared to reduce the 'source' supply below the compensation point resulting in smaller fruit with lower TSS (Table 2). Fruit removal plus defoliation appeared to balance source and sink size at the beginning of the experiment, resulting in similar fruit set and weight than the controls (Table 2). When more fruit were set and defoliation continued, source photosynthate supply was apparently lower than fruit sink demand and mature fruit TSS was reduced (Fig. 3C). This was supported by mature fruit TSS not being higher in the fruit removal treatment (Table 4). Apparently, the plant was able to adjust to the fruit load (Table 2) and had similar fruit sugar accumulation similar to the controls. These data suggested that each mature photosynthetic leaf could support the full development of about three fruit and allow maximum final fruit sugar content. This ratio may vary with cultivars. This research supported and expanded on previous work with papaya that defloration increases new flower set (Awada, 1967) and fruit

Table 6. Effect of $40 \%$ fruit thinning and $65 \%$ defoliation on fruit sugar (sum of sucrose, fructose, and glucose), of 'Line 8' Papaya 1 week and 3 weeks before color break. Fruit were harvested 3 weeks after treatment.

\begin{tabular}{lcc}
\hline & \multicolumn{2}{c}{ Fruit sugar $\left(\mathrm{g} \cdot \mathrm{kg}^{-1}\right)$} \\
\cline { 2 - 3 } Treatment & 3 weeks before harvest & 1 week before harvest \\
\hline Control & $26 \mathrm{~b}^{\mathrm{z}}$ & $62 \mathrm{a}$ \\
Fruit thinned & $30 \mathrm{a}$ & $68 \mathrm{a}$ \\
Defoliated & $26 \mathrm{~b}$ & $54 \mathrm{~b}$
\end{tabular}

${ }^{\mathrm{z}}$ Mean $(\mathrm{n}=3)$ separation within columns by Waller-Duncan k ratio $t$ test, $P<0.05$.

Table 7. Effect of defoliation $(66 \%)$ and fruit thinning (50\% fruit removal) on sucrose synthase and acid invertase enzyme activity in ripe 'Sunset' papaya fruit.

\begin{tabular}{lcc}
\hline \hline & \multicolumn{2}{c}{$\begin{array}{c}\text { Enzyme activity } \\
\text { Treatment }\end{array}$} \\
\cline { 2 - 3 } Trese $\mu \mathrm{mol} \cdot \mathrm{h}^{-1} \cdot \mathrm{g}^{-1}$ fresh $\left.\mathrm{wt}\right)^{\mathrm{z}}$ \\
\hline Control & Sucrose synthase & Acid invertase \\
Defoliated & $1.1 \pm 0.15$ & $619 \pm 22$ \\
Fruit thinned & $1.0 \pm 0.29$ & $739 \pm 186$ \\
\hline
\end{tabular}

${ }^{\mathrm{z}}$ Means $\pm \mathrm{SD}, \mathrm{n}=3$. 

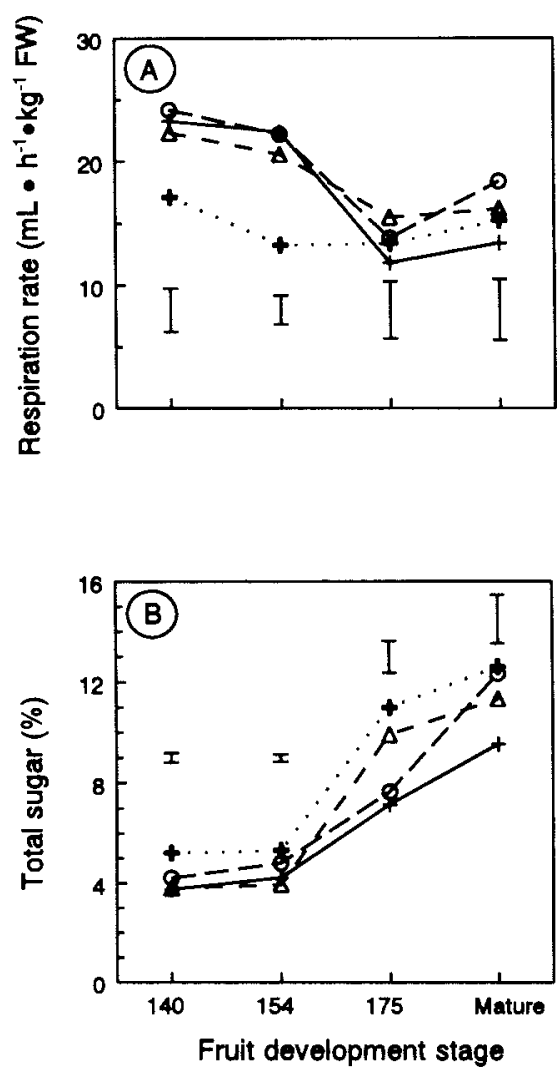

Fig. 5. (A) Fruit respiration rate, (B) total fruit flesh sugar content, (C) sucrose synthase (SS), (D) sucrose phosphate synthase (SPS), and (E) acid invertase (AI) activities of 'Sunset' papaya fruit at different fruit development stages as days after anthesis subject to, fruit removal $(\mathbf{+}, 80 \%$ fruit removed at the beginning of experiment), continual defoliation (,$+ 60 \%$ leaf removal), fruit removal plus continual defoliation $(\boldsymbol{\Delta})$ and control $(\bigcirc)$. Fruit were picked at the mature (color break) stage from the different treatments and may have taken slightly different times to reach maturity. Vertical bars in each graph indicate LSD $(P=0.05)$ among the four treatments at each individual development stage. There were no significant differences between treatments in SPS activity (D).

thinned to one per leaf node increased fruit size but did not affect fruit final TSS (Martinez, 1988).

Defoliation of papaya reduced fruit set and delayed young fruit growth leading to a long-term reduction in fruit production, although defoliation and fruit thinning treatment did not significantly influence papaya fruit production, during the 6 week experimental period. Failure to set fruit in every leaf axil was due to a combination of flower and fruit abortion and a change in flower type from hermaphrodite to staminate. Similar observations have also been reported for papaya (Awada, 1967) and other hermaphroditic species (Spears and May, 1988; Wilson, 1983).

Differences in cultivar fruiting characteristics and weather were the important factors that influenced papaya fruit growth, flesh dry matter percentage, and sugar accumulation (Figs. 1 and 2, Table 3). These differences in response to defoliation and fruit thinning in different seasons appeared to be caused by varying source-sink balances. Defoliation of 'Sunset' and 'Kamiya' was performed in the warm season (May to July) when the plants were bearing heavily fruit of all ages. Ripe fruit TSS declined 2 to 3 weeks after defoliation. In the 'Kapoho' and 'Line-8' defoliation experiment (Dec. 1996 to Jan. 1997), fruit set was reduced by a rainy period before artificial defoliation and fruit thinning. In addition, photosynthesis was probably reduced under the rainy and cloudy conditions, that occurred after treatment imposition and reduced the difference in assimilate supply between nondefoliated and defoliated plants. The different responses in TSS to fruit thinning that increased in 'Line 8' but not in 'Kapoho' and fruit weight that was reduced in 'Line-8' and increased in 'Kapoho', can possibly be related to their different growth characteristics. 'Line8 ' had a large leaf area per leaf (ca. $2000 \mathrm{~cm}^{2}$ ) and usually produced about three to four fruit per node (fruit weight about $460 \mathrm{~g}$ ). Removing fruit may reduce carbon importation rate into other fruit at the same node due to wound injury (the removal of a flower from the same node induced abortion of remaining flowers, personal observation), so that fruit weight was reduced but final TSS was increased in the fruit thinning treatment. 'Kapoho' usually produced only one small fruit per node (fruit weight about $350 \mathrm{~g}$ ) and had a higher shoot growth to fruit ratio; greater thinning of 'Kapoho' may have led to increased fruit size (Table 3).

Fruit growth and the time to maturity were altered by source-sink balance (Table 5). Nakasone (1986) reported that the growth period of papaya was prolonged about 2 weeks during Hawaii's cool season. Fruit set of 'Sunset' papaya in June reached the color break stage within $140 \mathrm{~d}$ while fruit set in October for the same cultivar required about $180 \mathrm{~d}$ to reach the color break stage while average air temperatures were 29 and $24{ }^{\circ} \mathrm{C}$ for June and Dec. 1996, respectively. Our defoliation data also suggested that assimilate availability could reduce fruit maturation time, in addition to the effect of

Table 8. Correlation coefficients of 'Sunset' papaya between individual sugars and total sugars and acid invertase and sucrose synthase activities across four developmental stages (140,154, and 175 DAA and mature fruit) and four treatments (control, continual defoliation: 60\% leaf defoliation, $80 \%$ fruit removed, and defoliation plus fruit removed at the beginning of experiment (same data as presented in Fig. 5).

\begin{tabular}{|c|c|c|c|c|c|c|c|c|c|}
\hline \multirow[b]{3}{*}{ Enzyme } & \multirow[b]{3}{*}{ Stage } & \multicolumn{8}{|c|}{ Correlation coefficient ${ }^{2}$} \\
\hline & & \multicolumn{2}{|c|}{ Sucrose } & \multicolumn{2}{|c|}{ Glucose } & \multicolumn{2}{|c|}{ Fructose } & \multicolumn{2}{|c|}{ Total } \\
\hline & & $r$ & $P$ & $r$ & $P$ & $r$ & $P$ & $r$ & $P$ \\
\hline \multirow[t]{2}{*}{ Invertase } & Same stage & 0.44 & 0.09 & 0.51 & 0.04 & 0.38 & 0.15 & 0.44 & 0.09 \\
\hline & One stage earlier & 0.80 & 0.0018 & 0.80 & 0.0017 & 0.80 & 0.017 & 0.83 & 0.0008 \\
\hline \multirow[t]{2}{*}{ Sucrose synthase } & Same stage & -0.36 & 0.17 & -0.21 & 0.44 & -0.25 & 0.36 & -0.29 & 0.28 \\
\hline & One stage earlier & -0.04 & 0.90 & 0.31 & 0.33 & 0.11 & 0.74 & 0.10 & 0.75 \\
\hline
\end{tabular}

${ }^{z_{n}}=16$ for same stage enzyme and sugar and $n=12$ for one stage earlier enzyme to sugar correlation. 
temperature and plant age. Fruit maturation was more rapid in the treatments where older fruit had been removed previously than in control and defoliated plants (Table 5, 175 DAA fruit). However, the sudden loss of photosynthetic capacity usually led to the mature fruit ripening sooner than the mature fruit on the nondefoliated treatment ('Kamiya', data not presented) and apparently delayed young fruit growth. Under long-term source limitation, papaya fruit size was reduced and sugar content tended to be lower but the fruit growth period was not significantly altered from the control (Table 5).

Fruit removal increased, and continual defoliation decreased AI activity (Fig. 5E) and sugar levels in young fruit (Fig. 5B). Our results suggested a relationship between photosynthetate supply and fruit AI activity. This result was consistent with tomato fruit that have lower vacuolar AI activity in smaller fruit (Klann et al., 1996) and a lower sugar content (Bucheli and Diovaud, 1994). SS activity was significantly lower in fruit from plants subjected to continual defoliation at 154 and 175 DAA and mature fruit than nondefoliated plants (Fig. 5C). However, SS activity was not significantly different at all four stages of fruit development between the fruit removal and the control treatments. SPS is the major enzyme contributing to sucrose accumulation, and it is affected by defoliation in muskmelon (Hubbard et al., 1990). In papaya, SPS activity was not significantly different between treatments at the later stages of fruit development (Fig. 5D). AI could be involved in sugar unloading during the late stage of papaya fruit development (Fig. 5E). Decreased SS activity in the defoliation treatment and the slight increase in SPS activity during maturation could also result in sugar unloading.

The source-sink ratio was a critical factor in controlling papaya fruit set (Tables 1 and 2), fruit growth (Table 5), development, and final quality of ripe fruit (Figs. 1 and 2A). New flower and fruit set could possibly be regarded as an index of plant assimilate supply. If leaf (source) assimilate capacity was larger than sink demand, then new flowers and fruit would continue to be set. When assimilate was limited, plant flower development would be arrested. This proposal was supported by fruit set being increased $20 \%$, compared to control plants, after $40 \%$ of the fruit were removed during a 6 week period (Table 1 ). In addition, there were $82 \%$ more new flowers when $80 \%$ of the more mature fruit were removed during the first 6 weeks of the experimental period than on control plants and 52\% more fruit in the first 8 weeks of the experiment (Table 2). In contrast, $75 \%$ defoliation reduced new fruit set $60 \%$, compared to the controls during the 6 weeks after defoliation. Continual defoliation reduced new fruit to less than one-third of controls in the first 8 weeks of defoliation and less than one-fourth of the controls in the $168 \mathrm{~d}$ experimental period (Table 2). During the first 8 weeks of treatment, the continual defoliated plus fruit removal plants and the fruit removal treated plants had similar new fruit set. As defoliation continued for more than 8 weeks, new fruit set was reduced. At the end of the $168 \mathrm{~d}$ experimental period, the continual defoliation plus fruit removal plants had less than half the new fruit set as the fruit removal treatment plants alone. Fruit set was similar between the control plants and the fruit removal treatment and three fold more than the continual defoliation treatment plants as the leaf to fruit ratio changed (Table 2). These results indicated that assimilate availability may be a major factor in controlling papaya new fruit set. Any environmental stress that reduced total photosynthetic capacity of a papaya plant would probably influence potential fruit production. If the photosynthetic capacity was insufficient to meet the demand of a reduced sink (fewer and smaller fruit), as probably occurred in the defoliation plus fruit removal treatment, final fruit TSS (sugar) was reduced.

Source-sink balance in papaya can be used to predict and adjust fruit production and sweetness. Fruit weight was smaller than the commercial requirement in 'Sunset' plants subjected to the continual defoliation experiment. A similar situation could occur commercially due to poor cultural (e.g., water and fertilizer) management. In this case, fruit thinning would be necessary to ensure marketable fruit size. Fruit abortion occurs in the first few weeks after anthesis, while fruit longer than $6 \mathrm{~cm}$ usually do not subsequently abscise (Ong, 1983) and therefore fruit abortion apparently can not fully adjust to the source-sink balance. It was observed that a plant having a high fruit load usually experienced reduced fruit sweetness and less fruit production the next season (Fig. 3). This observation might also apply to papaya plants exposed to other types of stresses (e.g., powdery mildew and mites). Adjustment of fruit number to leaf number could possibly result in desirable fruit size and more uniform month to month fruit production and fruit sweetness (Table 3 and 4). Our data indicate that each mature leaf can provide sufficient photosynthate for growth and development of about three fruit in the cultivar Sunset.

\section{Literature Cited}

Antognozzi, E., A. Tombesi, and A. Palliotti. 1992. Relationships between leaf area, leaf area index and fruiting in kiwifruit (Actinidia deliciosa). Acta Hort. 297:435-442.

Awada, M. 1967. Effects of defoliation and defloration on sex expression and growth of papaya (Carica papaya L.). Proc. Amer. Soc. Hort. Sci. 90:138-143.

Bertin, N. 1995. Competition for assimilates and fruit position affect fruit set in indeterminate greenhouse tomato. Ann. Bot. 75:55-65.

Boucher, T.J., D.G. Pferffer, J.A. Barden, and J.M. Williams. 1987. Effects of simulated insect injury on net photosynthesis of potted grapevines. HortScience 22:927-928.

Bucheli, P. and S. Diovaud. 1994. Sugar accumulation in tomato and partial purification of buffer-insoluble invertase. Phytochemistry 36:837-841.

Chacko, E.K., Y.T.N. Reddy, and T.V. Annthanaranan. 1982. Studies on the relationship between leaf number and area and fruit development in mango. J. Hort. Sci. 57:483-492.

Clegg, M.D., C.Y. Sullivan, and J.D. Eastin. 1978. A sensitive technique for the rapid measurement of carbon dioxide concentration. Plant Physiol. 62:924-926.

Fishler, M., E.E. Goldschmidt, and S.P. Monselise. 1983. Leaf area and fruit size on girdled grapefruit branches. J. Amer. Soc. Hort. Sci. 108:218-221.

Gross, K.C. 1988. A rapid and sensitive spectrophotometeric method for assaying polygalacturonase using 2-cyanoacetamide. HortScience 17:933934.

Hansen, P. 1982. Assimilation and carbohydrate utilization in apple. Proc. 21st Intl. Hort. Congr. 1:257-268.

Hubbard, N.L., S.C. Huber, and D.M. Pharr. 1989. Sucrose phosphate synthase and acid invertase as determinants of sucrose concentration in developing muskmelon (Cucumis melo L.) fruits. Plant Physiol.91:15271534.

Hubbard, N.L., D.M. Pharr, and S.C. Huber. 1990. Sucrose metabolism in ripening muskmelon fruit as affected by leaf area. J. Amer. Soc. Hort. Sci. 115:798-802.

Ito, P.J. 1976. The effect of leaf pruning on yield and quality of 'solo' papayas in Hawaii. Proc. Trop. Reg. Amer. Soc. Hort. Sci 101:45-50

Jensen, W.A. 1962. Botanical histochemistry: Principles and practices. W.H. Freeman, San Francisco.

Klann, E.M., B. Hall, and A.B. Bennett. 1996. Antisense acid invertase (TIV1) gene alters soluble sugar composition and size in transgenic tomato fruit. Plant Physiol. 112:1321-1330.

Koblet, W., M.C. Candolfl-Vasconcelos, W. Zweifel, and G.S. Howell. 
1994. Influence of leaf removal, rootstock, and training system on yield and fruit composition of 'Pinot Noir' grapevines. Amer. J. Enol. Viticult. 45:181-187.

Layne, D.R. and J.A. Flore. 1992. Photosynthetic compensation to partial leaf area reduction in sour cherry. J. Amer. Soc. Hort. Sci. 117:279-286.

Layne, D.R. and J.A. Flore. 1995. End product inhibition of photosynthesis in Prunus cerasus L. in response to whole-plant source-sink manipulation. J. Amer. Soc. Hort. Sci. 120:583-599.

Lyrene, P.M. 1992. Early defoliation reduces flower bud counts on rabbiteye blueberry. HortScience 27:783-785.

Maggs, D.H. 1964. Growth-rates in relation to assimilate supply and demand. I. Leaves and roots as limiting regions. J. Expt. Bot. 15:574583.

Marler, T.E., M.V. Mickelbar, and R. Quitugua. 1993. Papaya ringspot virus influences net gas exchange of papaya leaves. HortScience 28:322-324.

Martinez, O.R.Z. 1988. Estudio preliminar sobre El rendimiento de la papaya, Carica papaya L. var. 'Sunrise Solo'. Mediate raleo de frutus. Proc. Interamer. Soc. Trop. Hort. 32:74-78.

Mulas, M. 1997. Flower removal time and fruit quality in cactus pear (Opuntia indica Mill.) Acta Hort. 438:123-128.

Nakasone, H.Y. 1986. Papaya, p. 277-301. In: S.P. Monselise (ed.). CRC handbook of fruit set and development. CRC Press, Boca Raton, Fla.

Ong, H.T. 1983. Abortion during the floral-fruit development in Carica papaya in Serdang, Malaysia. Pertanika 6:105-107.

Palmer, J.W., Y.L. Cai, and Y. Edjamo. 1991. Effect of part-tree flower thinning on fruiting, vegetative growth and leaf photosynthesis in 'Cox's Orange Pippin' apple. J. Hort. Sci. 66:319-325.

Paull, R.E., N.J. Chen, J. Deputy, H. Huang, G. Cheng, and F. Gao. 1984. Litchi growth and compositional changes during fruit development. J. Amer. Soc. Hort. Sci. 109:817-821.
Paull, R.E., W. Nishijima, M. Reyes, and C. Cavaletto. 1997. A review of postharvest handling and losses during marketing of papaya (Carica papaya L). Postharvest Biol. Technol. 11:165-179.

Pavel, E.W. and T.M. Dejong. 1993. Source- and sink-limited growth periods of developing peach fruits indicated by relative growth analysis. J. Amer. Soc. Hort. Sci. 118:820-824.

Ramirez, D.R., T.C. Wehner, and C.H. Miller. 1988. Source limitation by defoliation and its effects on dry matter production and yield in cucumber. HortScience 23:704-706.

Roper, T.R. and W.H. Loescher. 1987. Relationships between leaf area per fruit and fruit quality in 'Bing' sweet cherry. HortScience 22:1273-1276

Snelgar, W.P. and P.J. Martin. 1997. Relationship between leaf area index and fruit size in kiwifruit. Acta Hort. 444:199-204.

Spears, Jr., E.E. and P.G. May. 1988. Effect of defoliation on gender expression and fruit set in Passiflora incarnata. Amer. J. Bot. 75:18421847.

Stacey, D.L. 1983. The effect of artificial defoliation on the yield of tomato plants and its relevance to pest damage. J. Hort. Sci. 58:117-120.

Toldam-Anderson, T.B. and P. Hansen. 1993. Source-sink relations in fruits. VII. Effects of pruning in sour cherry and plum. Gartenbauwissenschaften 58:205-208.

Von Caemmerer, S. and G.D. Farquhar. 1984. Effects of partial defoliation, changes of irradiance during growth, short-term water stress and growth at enhanced $\mathrm{p}\left(\mathrm{CO}_{2}\right)$ on the photosynthetic capacity of leaves of Phaseolus vulgaris L. Planta 160:320-329.

Welles, G.W.H. and K. Buitellar. 1988. Factors affecting soluble solids content of muskmelon (Cucumis melo L.). Neth. J. Agr. Sci. 36:239-246. Wilson, M.F. 1983. Plant reproductive ecology. Wiley, New York.

Yee, W., E.K. Akamine, G.M. Aoki, R.A. Hamilton, F.H. Haramoto, R.B. Hine, O.V. Holtzman, J.T. Ishida, J.T. Keeler, and H.Y. Nakasone. 1974. Papayas in Hawaii. Univ. Hawaii Coop. Ext. Serv. Circ. 436. 